Gwóźdź K., Parkitna A., The role of the discount rate in efficiency measuring process of food industry enterprises over the economic crisis in Poland, „Ekonomia i Prawo. Economics and Law”, Polszakiewicz B., Boehlke J. (ed.), Vol. 14, No. 4/2015, pp. 415-426. DOI: http://dx.doi. org/10.12775/EiP.2015.027.

\title{
THE ROLE OF THE DISCOUNT RATE IN EFFICIENCY MEASURING PROCESS OF FOOD INDUSTRY ENTERPRISES OVER THE ECONOMIC CRISIS IN POLAND
}

\author{
SUMMARY
}

The work reads about the subject of the efficiency evaluation in the food industry enterprises over the economic crisis in Poland. The authors tried to prove the theorem that the applied assumption of using the constant discount rate in assessing enterprises efficiency is incorrect. In the first step, the definition of enterprises efficiency as well as the factors molding economic efficiency are shown. The measures of assessing enterprises efficiency are also shown. The fundamental part of the work is the empirical research, which proves the aim of the work. The content of the work consists of the research results related to ROE, own equity multiplier, risk premium, and weighted average cost of capital. The discount rate can be influenced by many factors e.g. Central Bank monetary policy, fiscal policy, capital structure, exchange rate, the value of gross domestic product. It is hard to expect that they will not change. To evaluate the real enterprise efficiency, its authentic measures should be assessed.

"Katarzyna Gwóźdź, Wrocław University of Technology, Faculty of Computer Science and Management, Department of Management Systems, ul. Smoluchowskiego 25, 50-372 Wrocław, Poland, phone: +48 7132042 39, e-mail: katarzyna.gwozdz@pwr.edu.pl (corresponding author).

** Agnieszka Parkitna, Wrocław University of Technology, Faculty of Computer Science and Management, Department of Management Systems, ul. Smoluchowskiego 25, 50-372 Wrocław, Poland, phone: +48 7132028 64, e-mail: agnieszka.parkitna@pwr.edu.pl.

$\diamond$ The article was funded by Ministry of Science and Higher Education. 
If we assume that there is only positive risk premium and constant discount rate, the real efficiency level is counterfeited, especially during the periods of market crises. It is deceptive for investors and enterprise capital managers. The real assessment of efficiency measures is important because of the ambiguity of efficiency concept. In our case, it is simultaneously implied as effectiveness, economy, and proficiency. Considering the aim of the work, the measures of efficiency put to the research process were expressed by authoritative financial factors.

Keywords: capital cost; capital structure; enterprises efficiency; discount rate JEL Classification: G01; G31; G32

\section{INTRODUCTION}

The work objective is to show that the previously used assumption, of using the constant discount rate in assessing the enterprise efficiency, is incorrect. That is why, the empirical research was realized at the example of food industry branch, which allowed to make a well connection with such formulated aim. In the source literature, there is an opinion about positive, accepted value of risk premium. The theorists do not admit the notion that risk premium could be negative. In consequence, it would mean that there were a possibility where investing in safer securities would be more efficient than the value of shares. The securities are characterized by lower return rate as well as lower risk. Polish Market is so specific and developing that such a situation often happens. Unfortunately, the fact disagrees with previously used approach of estimating the risk to assess cash flows. It is necessary to consider real, variable discount rate. Without such an assumption, obtaining efficiency measure and its evaluation by cash flows will not reflect both the real situation in enterprise and real level of capital cost. It means it will not be possible to get the authoritative evaluation of enterprise efficiency.

\section{THE ECONOMIC EFFICIENCY OF ENTERPRISES}

Many theorists of the subject, apart from field, think that the efficiency is the basic category and it is used to evaluate the working of economic entity. March and Sutton aptly found out that "the different definition of efficiency is one of more preserved subjects in research conducted by organizations" 1 .

${ }^{1}$ J.G March., R.I. Sutton, Crossroads - Organizational Performance as a Dependent Variable, “Organization Science”, Vol. 8, No. 6/1997, pp. 698-706. 
It can apply for relation between: effects, aims, expenditures, and costs expressed by both structural and dynamic way. It can decide about the organization as a managing entity determining its functioning and the effects of the efficiency determine both the development and increase of the economic organizations ${ }^{2}$.

If we want the effectively used economic resources, we should use the rule of rational management, which is optimal and profitable selection during the decision-making process in the range of intended aims, resources, and methods of the aims realization ${ }^{3}$. The economic efficiency is "an effect of the activity of an economic entity or a determined venture, as a result of the rela-

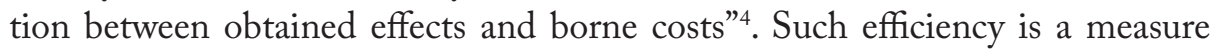
of organization achievements not only on the optional level, but also on the strategic one.

Many economists, who deliberate the efficiency notion, relate the notion to the proficiency action which is defined on the ground of praxeology $\mathrm{y}^{5}$. The composition of elements of proficiency action mentioned above, which are needed to proficiency action bases on determining the relation between aim, effect, and cost. The efficiency is often identified with effectiveness. Helms paid attention to the difference between those two notions claiming that the "efficiency refers to do things in the accurate way whereas effective-

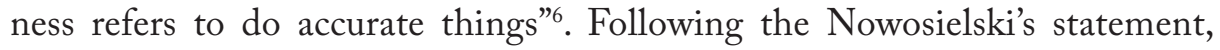
it can be said that the effectiveness is a positively evaluated agreement between the action result and its intended aim. On the other hand, the efficiency is the feature of many actions which give the positive result, no matter if it was intended or not ${ }^{7}$. The efficiency is both a measure of the management effectiveness and a tool to create strong competition superiority. It should be quoted, "even the most silly man is able to increase the work productivity if

${ }^{2}$ G. Osbert-Pociecha, Relacja między efektywnościq i elastycznościq organizacji, [in:] T. Dudycz, Ł. Tomaszewicz (ed.), Efektywnośc - rozważania nad istotq i pomiarem, Wydawnictwo AE we Wrocławiu, Wrocław 2007, pp. 337-349.

${ }^{3}$ E. Skrzypek, Efektywność ekonomiczna jako ważny czynnik sukcesu organizacji, „Prace Naukowe Uniwersytetu Ekonomicznego we Wrocławiu”, No 262/2012, pp. 313-325.

${ }^{4}$ J. Penc, Leksykon biznesu, Placet, Warszawa 1997, p. 99.

5 R. Walkowiak, Prakseologiczne zasady sprawnego dziatania, „Zeszyt Naukowy Ekonomia i Zarządzanie”, No. 1/2011, p. 29.

${ }^{6}$ M.M. Helms, Encyklopedia of Management, Thompson Gale, Detroit 2006, p. 211.

7 S. Nowosielski, Skuteczność i efektywność realizacji procesów gospodarczych, [in:] T. Dudycz (ed.), Mikroekonomiczne aspekty funkcjonowania przedsiębiorstw, Wydawnictwo AE we Wrocławiu, Wrocław 2008, pp. 39-46. 
he devotes the accurate amount of resources. The real trick means increasing the efficiency without extra investments in new devices and technologies".

\subsection{THE FACTORS WHICH CREATE ECONOMIC EFFICIENCY}

There are four, closely-connected factors of economic efficiency: costs, effects, time, and risk. Their quantitative analysis is the basic element of economic efficiency assessment. The role of time factor increases together with extending time horizon, after which the effects of previously borne costs has been generated. The theory of the money value in time, used in the efficiency calculation, amounts all effects calculations to the comparable values. The values can be compared to fragmentary flows in particular years, in the period of the venture functioning, and to the combinations of variants, characterized with similar amount of incomes gained in different periods of time. The rule, which comes from the theory of money value in time, says the later the costs are borne and the sooner the effects are gained, the higher the realized ventures efficiency is ${ }^{9}$. The last factor that influences the economic efficiency is a risk factor. It is an inseparable element of every business activity and, like in the case of time factor, it comes into prominence with longtime investments. Finally, in connection with considering time factor and risk in the efficiency calculation, the importance of good cash flows assessment is emphasized. The flows guarantee the increase of economic entity in the long time horizon.

\subsection{THE ASSESSMENT MEASURES OF ECONOMIC EFFICIENCY OF AN ENTERPRISE}

We can identify two basic approaches to the efficiency assessment. The first one finds positive cash flows as a basic value. The second one finds that positive financial net result (net profit) is the main part.

The correct calculations of net cash flows value need to be precisely determined e.g. which elements should be included as streams of cash flows or it is crucial to estimate the value in the following years of an enterprise activity ${ }^{10}$.

${ }^{8}$ T.P. Sankowski, Wiedza o wiedzy, Canadian International Management Institute, No. 18/2006 [offprint] „Global Business”, Vol. 9, No. 78/2000.

9 J. Pawłowski, Wybrane metody oceny efektywności finansowej przedsięwzięć gospodarczych, Wydawnictwo Uniwersytetu Eódzkiego, Łódź 2007, pp. 49-50.

${ }_{10}$ T. Dudycz, Ł. Tomaszewicz, Efektywność — rozważania nad istotnq i pomiarem, Wydawnictwo Akademii Ekonomicznej im. Oskara Langego we Wrocławiu, Wrocław 2007, pp. 426-427. 
In this approach, one of the essential parameters - which influence the evaluation of efficiency - is the level of capital cost assumed to discount the estimated cash flows. Mistakes, which can happen during its assessment, can lead to misallocation of capita ${ }^{11}$. The profitability of financial assets owned by an enterprise, invested by shareholders and capital creditors, should be high enough to meet investors' expectations. The capital cost of an enterprise is, first of all, dependent on both the way of use and profitability by an enterprise, not on its source. That is why the notions "capital cost", "desired return rate" as well as "opportunity capital cost" and "discount rate" are the mostly used variables. The establishment of capital cost lies in assessing with available methods, separating cost of debt and equity cost, and then calculating weighted average cost of capital (WACC). The structure of capital determines the weighs of equity and borrowed capital. The only possibility is not to assess the exact calculation of capital cost. The base to determine its level is an enterprise return rate expected by those who invested in securities. In fact, the achieved return rate by investors depends on real enterprise profitability as well as prices of current shares and debentures in the capital market ${ }^{12}$.

The second approach is connected with net profit, which is the basic value of efficiency. The profitability is calculated on the basis of the net profit and it is the main criteria of efficiency. The profit is the main aim of economic entity functioning and its role comes from the function, which can be fulfilled in the enterprise (on the condition of the accurate entity management). When we accept the net profit as a measure, it obviously motivates investors to do business and to operate it. The evaluation of efficiency, from an angle of profit, induces to maximize the sale, influences cost economy, and contributes to reduce requesting factors of production, and induces to develop an enterprise. Moreover, the profit is the basic source of enlarge the owners' equity capital, which indirectly influences the enterprise market position. On the basis of deliberations above, it is induced to accept the theory of followers of the approach that net profit us the fundamental value for estimating the enterprises economic efficiency.

11 T. Wiśniewski, Btędy szacowania kosztu kapitatu w decyzjach inwestycyjnych $i$ ich skutki, „Badania operacyjne i decyzje”, No. 3/2008, pp. 107-116.

12 Z. Klimiuk, Jak struktura i koszt kapitatu wptywaja na efektywnośc firmy, www.infor.pl (01.09.2015). 


\section{THE RESEARCH METHOD}

The main aim of the research was to show that using the constant discount rate in assessing the enterprises efficiency is incorrect and does not reflect the real enterprises situation in the market. The analysis was conducted on the basis of real data, comparing both measures which influence the efficiency estimation: the level of capital cost accepted to discount planned flows, especially to set risk premium and capital profitability calculated on the basis of a profit. The research covered 10-years period, including the period before and after the economic crisis (2004-2013). The analysis was realized as the example of food branch, the criteria of enterprises choice concerned the definite period when an enterprise was listed on the Polish stock exchange.

The process, first of all, covered the analysis of financial reports. It helped to collect the data needed to do the calculation. The source was the quarterly reports of publicly traded companies. The first step of the research was to determine the profitability of analyzed companies by the index of return on equity (ROE). The completing of enterprise profitability research was an analysis of equity multiplier, which is the risk measure of enterprise activity. The process of empirical research concentrated mainly on the analysis of the discount rate, necessary to calculate the current value of cash flows as a valuation of enterprise efficiency. In the context of assessing the capital cost, the authors show the final results of assessing the weighted average cost of capital. The uniqueness and generality of establishment the particular costs, included in WACC, was not presented as separate parts. On the other hand, risk premium was especially taken into consideration (as a component of setting capital cost with CAPM method). The issue was considered to emphasize the possibility of existence different values of risk premium, including the one which was extremely negative, depending on the interpretation of elements which determine the premium.

\section{THE MEASUREMENT OF FOOD INDUSTRY ENTERPRISES EFFICIENCY OVER THE ECONOMIC CRISIS IN POLAND}

In the work, the results of conducted research was presented as well as incorrectness of used assumption concerning the constant discount rate, which is used in evaluation the enterprises efficiency and pricing the capital cost was confirmed. The possibility of using different techniques to price the risk premium was also taken into consideration. 


\subsection{THE PROFITABILITY OF EQUITY CAPITAL — THE RESULTS}

The sectorial comparison of examined branch reflects the effects of financial crisis, which was presented in figures 1 and 2. Most enterprises of analyzed sector noted significant fall of capital profitability. It was caused by the decline of pork price in Poland as well as its excessive supply in Europe and strong zloty exchange rate. The exception of the existed situation in the market was the profitability quotations of Colian and Pepees enterprises, the increase of their profitability came from the decision to raise share capital. It was a short term procedure because, from the end of 2008, the companies were following the trend, which existed in the branch. The values of calculated indicator for analyzed companies were presented in figures 1 and 2 (quarterly values). On the other hand, in table 1, the annual data of presented indicator was shown.

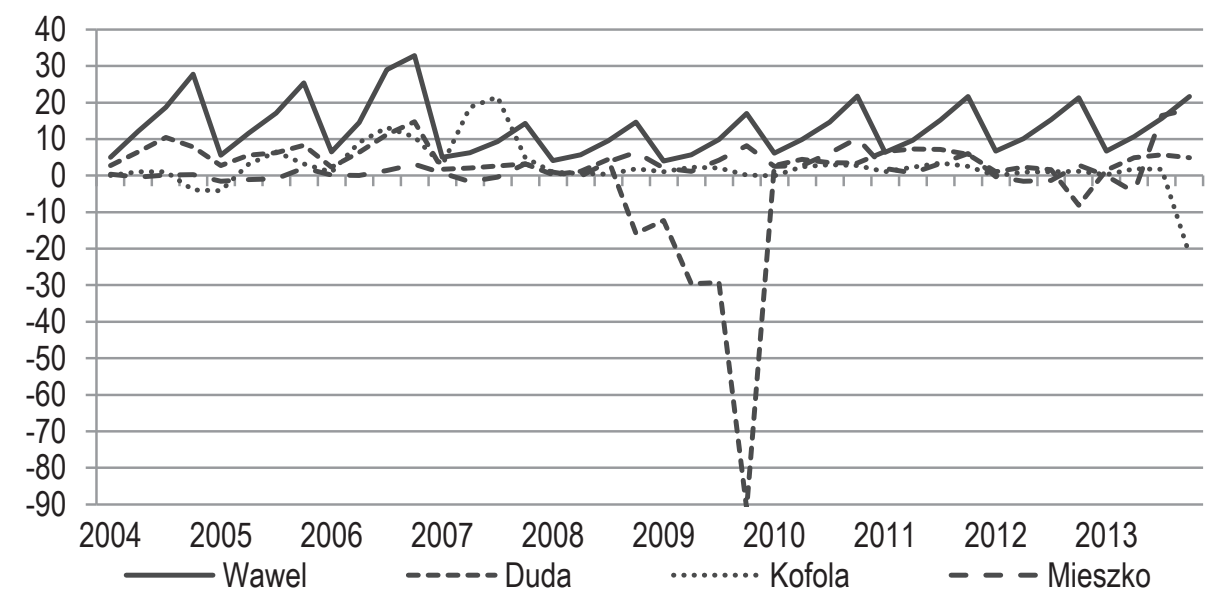

Figure 1. ROE - part 1 (in \%)

Source: Own preparation based on the financial reports. 


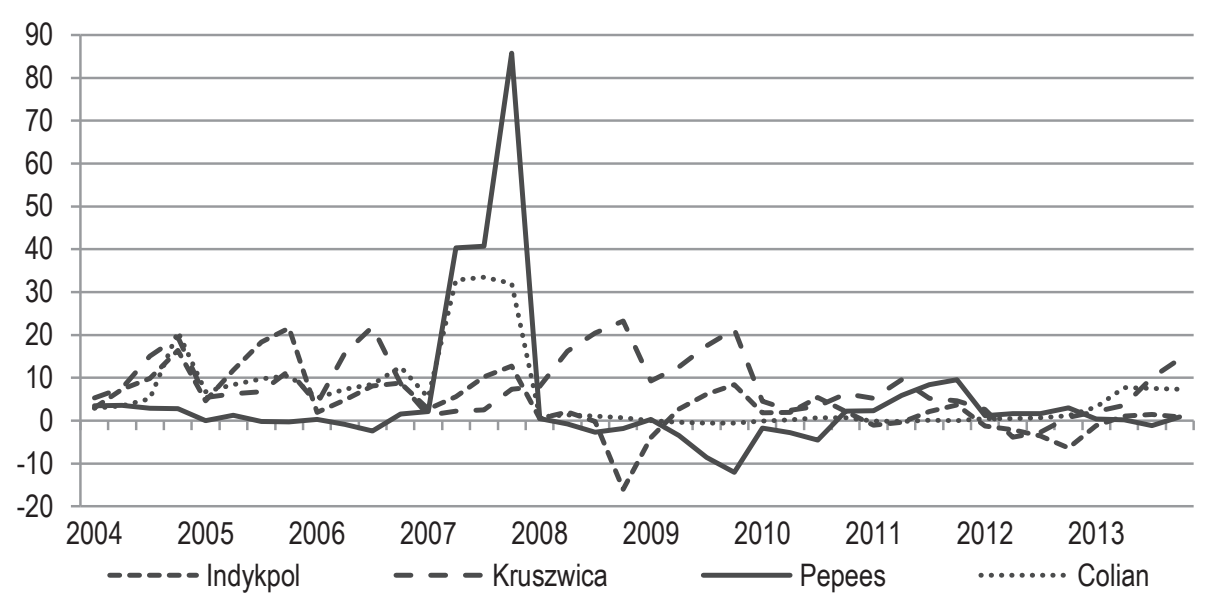

Figure 2. ROE - part 2 (in \%)

Source: Own preparation based on the financial reports.

Table 1. ROE - the comparison of companies against the sector (in \%)

\begin{tabular}{|c|c|c|c|c|c|c|c|c|c|c|}
\hline YEAR & 2004 & 2005 & 2006 & 2007 & 2008 & 2009 & 2010 & 2011 & 2012 & 2013 \\
\hline Colian & 20.73 & 10.49 & 12.52 & 32.02 & 0.71 & -0.58 & 0.67 & 0.03 & 1.16 & 7.32 \\
\hline Duda & 7.82 & 8.31 & 14.75 & 3.19 & -15.82 & -91.15 & 3.49 & 5.76 & -8.16 & 4.94 \\
\hline Indykpol & 16.39 & 21.62 & 8.81 & 12.69 & -16.01 & 8.37 & 2.11 & 3.69 & -6.32 & 0.92 \\
\hline Kofola & -3.90 & 3.23 & 10.55 & 4.95 & 1.87 & 0.18 & 2.79 & 2.48 & 1.23 & -21.61 \\
\hline Kruszwica & 19.47 & 11.65 & 8.68 & 7.36 & 23.23 & 21.28 & 6.27 & 4.59 & 0.77 & 14.37 \\
\hline Mieszko & 0.23 & 2.04 & 3.06 & 3.26 & 6.34 & 8.23 & 10.26 & 6.03 & 2.89 & 18.20 \\
\hline Pepees & 2.80 & -0.24 & 1.56 & 85.76 & -1.84 & -12.02 & 2.19 & 9.56 & 2.98 & 0.85 \\
\hline Wawel & 27.72 & 25.38 & 32.81 & 14.25 & 14.66 & 17.06 & 21.81 & 21.60 & 21.32 & 21.62 \\
\hline Sector & 11.92 & 11.25 & 10.38 & 10.76 & 1.62 & 8.31 & 9.86 & 6.85 & 5.34 & 6.18 \\
\hline
\end{tabular}

Source: ROE for enterprises: own preparation based on the financial reports; ROE for sector: Biznesradar.pl, http://www. biznesradar.pl (15.06.2015).

Analyzing the annual data, you can refer to ROE value of food industry branch. The profitability of the branch, in the examined period of time, has got the average value of about $8 \%$, which shows the effects of crisis in the whole branch. In the case of enterprises (Colian, Pepees) the capital gained from the stock exceeded the possibilities of their effective use and was only the action to rebuild the accurate structure of the capital. In the further process of analyzing the profitability, the calculations was conducted for capital multiplier, which reflects the financial risk and shows more precisely the use of financial leverage. The results of the calculations are presented in table 2 . 
Table 2. The capital multiplier of analyzed enterprises

\begin{tabular}{|c|c|c|c|c|c|c|c|c|c|c|}
\hline YEAR & 2004 & 2005 & 2006 & 2007 & 2008 & 2009 & 2010 & 2011 & 2012 & 2013 \\
\hline Colian & 1.82 & 1.82 & 1.73 & 2.07 & 1.00 & 1.00 & 1.00 & 1.00 & 1.00 & 1.00 \\
\hline Duda & 1.78 & 1.94 & 2.05 & 1.65 & 2.21 & 1.97 & 1.84 & 1.67 & 2.25 & 2.04 \\
\hline Indykpol & 2.88 & 2.38 & 2.10 & 1.97 & 2.60 & 2.36 & 2.48 & 2.84 & 2.90 & 2.74 \\
\hline Kofola & 2.83 & 2.80 & 2.67 & 1.57 & 1.15 & 1.13 & 1.12 & 1.14 & 1.09 & 1.11 \\
\hline Kruszwica & 2.94 & 2.90 & 2.70 & 2.68 & 2.24 & 1.69 & 1.84 & 2.00 & 1.86 & 1.43 \\
\hline Mieszko & 2.70 & 2.85 & 2.84 & 2.47 & 2.31 & 2.17 & 2.04 & 3.12 & 3.13 & 2.65 \\
\hline Pepees & 1.54 & 1.46 & 1.50 & 1.85 & 1.58 & 1.63 & 1.44 & 1.61 & 1.57 & 1.52 \\
\hline Wawel & 1.68 & 1.83 & 1.50 & 1.34 & 1.35 & 1.34 & 1.34 & 1.44 & 1.40 & 1.37 \\
\hline
\end{tabular}

Source: Own preparation based on the financial reports.

The levels of the multiplier, in particular periods of time, show the overuse of financial leverage. Its value should not be too high. The level higher than „1 means that the enterprises of food industry involved foreign capitals to fund their activity too intensively.

\subsection{WEIGHTED AVERAGE COST OF CAPITAL — THE RESULTS}

While the theory and practice agree with the assessment of capital cost, the equity capital cost is still the object of researchers interest. First of all, there is no universal method dedicated to all enterprises. Many assumptions concerned four generally approved models that are other-worldly (built-up model, discounted dividend model, CAPM, APT) e.g. assuming the constant dividend increase, subjectivism of factors selection, and adequacy of the method. That is why, in the process of data analysis, the CAPM model was accepted. Risk premium establishment is the most common research problem connected with CAPM model.

In the research, three approaches to establish risk premium were used. They differ from each other because of the level of sensitivity. The difference between presented approaches relates to different treatment of market-rate return $(\mathrm{Rm})$ represented by return rate from WIG (Warsaw Stock Exchange Index). Premium (1) considers the changes of WIG rate towards the beginning of the year. Premium (2) accepts daily return rate from WIG and Premium (3) takes into account the average daily value of WIG return rate in the given year. The risk-free return rate was identical in every approach and considers the value on the given day. The results of assessed risk premium were presented in figure 3. 


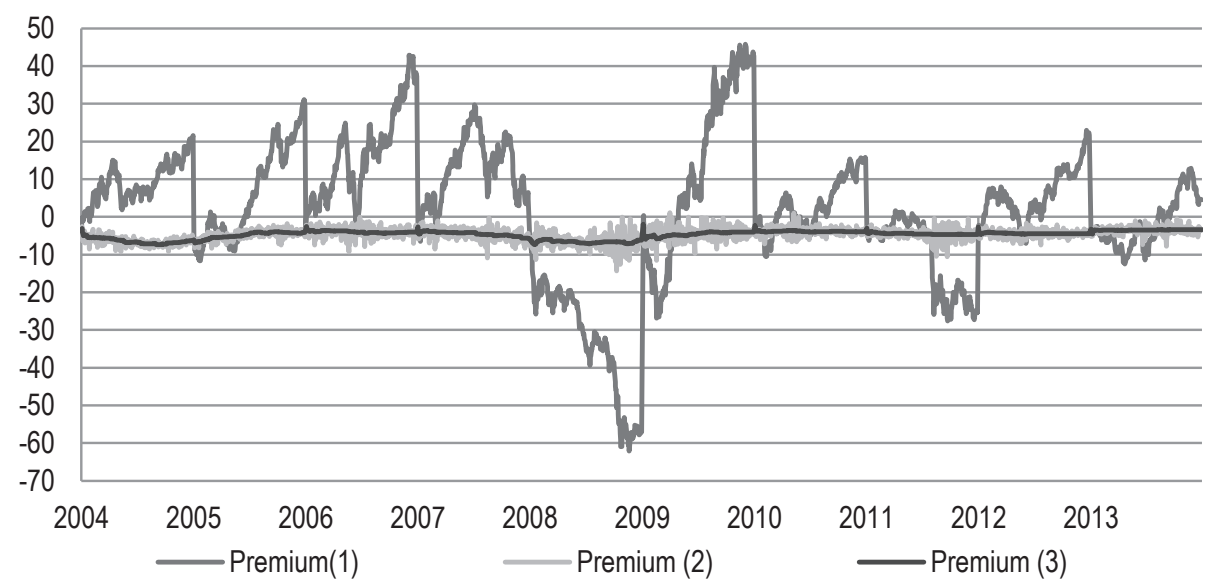

Figure 3. Risk premium assessed with established (in \%)

Source: K. Gwóźdź, Assessing the non-financial investment profitability with variable discount rate, Institute of Economic Research Working Papers, No. 16/2015.

Used techniques to assess risk premium allow to prove the aim of the research. The negative risk premium happens, especially over the crisis period. Premium (1) reflects short term behavior in the market and is in accordance with the market situation in the given period of time - in other words, it is sensitive to reflecting critical situations in the period. Premium 2 and 3 have negative values, which comes from really low values of $\mathrm{WIG}^{13}$ return rate, compared with the values of treasury bills, where the return rate was always positive. Such significant differences between return rate from WIG and return rate from treasury bills lead to negative values of risk premiums establishment. The real market data shows that, against the theorists views, it is accepted in precise efficiency evaluation to assume real risk premium, which is negative. As a consequence, in the critical period, it is more profitable to invest in safer securities than in shares. In assessing equity capital cost, premium (1) was accepted because it shows the current situation in the market.

The current risk premium establishment allows to precisely assess the equity capital cost and further to set enterprise capital cost (WACC). The figures 4 and 5 show the results of assessed capital cost used to discount cash flow.

${ }^{13}$ WIG value in the analyzed period characterized with values from about $-8 \%$ to about $6 \%$. 


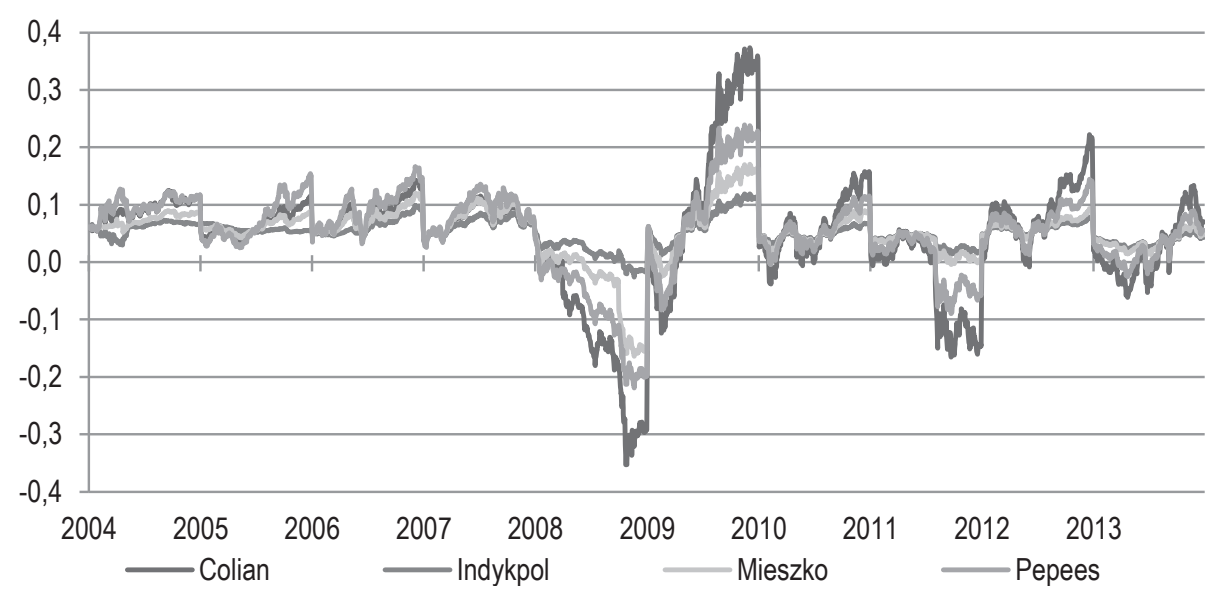

Figure 4. WACC — part 1

Source: Own preparation based on the financial reports.

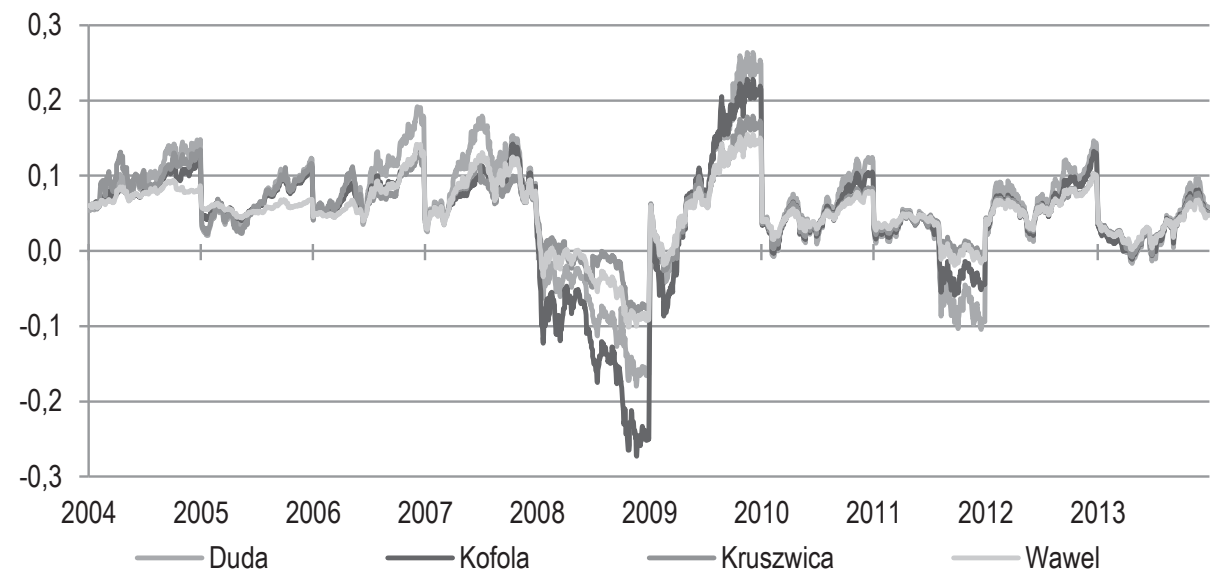

Figure 5. WACC - part 2

Source: Own preparation based on the financial reports.

The conducted analyzes proves the variability of discount rate in examined period. It denies the notion from the literature that the discount rate is constant. Using variable discount rate reflects in other values of cash flows, which causes the accurate evaluation of enterprise efficiency. 


\section{CONCLUSIONS}

In the work, the issue of evaluation enterprise efficiency was presented. The specificity of Polish food market, which characterized with negative risk premium, was shown. The premium is a result of economic environment. The authors tried to present the economic situation influence on cost and capital profitability. The research allows to select risk premium assessment to evaluate enterprise efficiency, especially considering food industry. The research shows that it is necessary to change the method range: the use of constant discount rate. Only the authentic assessment of risk premium will reflect the real situation in the market.

\section{BIBLIOGRAPHY}

Biznesradar.pl, http://www.biznesradar.pl (15.06.2015).

Dudycz T., Tomaszewicz Ł., Efektywność - rozważania nad istotna i pomiarem, Wydawnictwo Akademii Ekonomicznej im. Oskara Langego we Wrocławiu, Wroclaw 2007.

Gwóźdź K., Assessing the non-financial investment profitability with variable discount rate, Institute of Economic Research Working Papers, No. 16/2015.

Helms M.M., Encyclopedia of Management, Thompson Gale, Detroit 2006.

Klimiuk Z., Jak struktura i koszt kapitatu wptywajq na efektywnośc firmy, www.infor. $\mathrm{pl}(01.09 .2015)$.

March J.G., Sutton R.I., Crossroads - Organizational Performance as a Dependent Variable, "Organization Science", Vol. 8, No. 6/1997, http://dx.doi.org/10.1287/orsc.8.6.698.

Nowosielski S., Skuteczność i efektywność realizacji procesów gospodarczych, [in:] T. Dudycz (ed.), Mikroekonomiczne aspekty funkcjonowania przedsiębiorstw, Wydawnictwo AE we Wrocławiu, Wrocław 2008.

Osbert-Pociecha G., Relacja między efektywnościq i elastycznościq organizacji, [in:] T. Dudycz, Ł. Tomaszewicz (ed.), Efektywność - rozważania nad istota i pomiarem, Wydawnictwo AE we Wrocławiu, Wrocław 2007.

Pawłowski J., Wybrane metody oceny efektywności finansowej przedsięwzię́ gospodarczych, Wydawnictwo Uniwersytetu Eódzkiego, Łódź 2007.

Penc J., Leksykon biznesu, Placet, Warszawa 1997.

Sankowski T.P., Wiedza o wiedzy, Canadian International Management Institute, No. 18/2006 [offprint] „Global Business”, Vol. 9, No. 78/2000.

Skrzypek E., Efektywność ekonomiczna jako ważny czynnik sukcesu organizacji, „Prace Naukowe Uniwersytetu Ekonomicznego we Wrocławiu", No 262/2012.

Walkowiak R., Prakseologiczne zasady sprawnego dziatania, „Zeszyt Naukowy Ekonomia i Zarządzanie”, No. 1/2011.

Wiśniewski T., Btędy szacowania kosztu kapitatu w decyzjach inwestycyjnych i ich skutki, „Badania operacyjne i decyzje”, No. 3/2008. 